\title{
Expression of Interferon Lambda 4 Is Associated with Reduced Proliferation and Increased Cell Death in Human Hepatic Cells
}

\author{
Olusegun O. Onabajo, Patricia Porter-Gill, Ashley Paquin, Nina Rao, Luyang Liu, \\ Wei Tang, Nathan Brand, and Ludmila Prokunina-Olsson
}

Interferon lambda 4 (IFN- $\lambda 4$ ) is a novel type-III interferon that can be generated only in individuals carrying a $\Delta \mathrm{G}$ frame-shift allele of an exonic genetic variant (rs368234815- $\Delta \mathrm{G} / \mathrm{TT}$ ). The rs368234815- $\Delta \mathrm{G}$ allele is strongly associated with decreased clearance of hepatitis $\mathrm{C}$ virus (HCV) infection. Here, we further explored the biological function of IFN- $\lambda 4$ expressed in human hepatic cells-a hepatoma cell line HepG2 and fresh primary human hepatocytes (PHHs). We performed live confocal imaging, cell death and proliferation assays, mRNA expression profiling, protein detection, and antibody blocking assays using transient and inducible stable in vitro systems. Not only did we observe significant intracellular retention of IFN $-\lambda 4$ but also detected secreted IFN- $\lambda 4$ in the culture media of expressing cells. Secreted IFN- $\lambda 4$ induced strong activation of the interferon-stimulated genes (ISGs) in IFN- $\lambda 4$-expressing and surrounding cells in transwell assays. Specifically, in PHHs, secreted IFN- $\lambda 4$ induced expression of the CXCL1O transcript and a corresponding pro-inflammatory chemokine, IP-10. In IFN- $\lambda 4$-expressing HepG2 cells, we also observed decreased proliferation and increased cell death. All IFN- $\lambda 4$-induced phenotypesactivation of ISGs, decreased proliferation, and increased cell death — could be inhibited by an anti-IFN- $\lambda 4$-specific antibody. Our study offers new insights into biology of IFN- $\lambda 4$ and its possible role in HCV clearance.

\section{Introduction}

$\mathrm{W}$ ITH MORE THAN 170 million infected individuals, hepatitis $\mathrm{C}$ virus (HCV) infection represents a significant healthcare burden worldwide (Mohd Hanafiah and others 2013). HCV infection is treated with interferon (IFN)- $\alpha$-based regimens and recently approved IFN- $\alpha$-free direct-acting antiviral agents (DAA) (Liang and Ghany 2013). Genome-wide association studies identified a single nucleotide polymorphism rs12979860, located upstream of the IFNL3 (IL28B) gene and thus initially referred to as the "IL28B marker," as one of several genetic variants strongly predictive of $\mathrm{HCV}$ clearance (Ge and others 2009; Thomas and others 2009).

Further studies showed that rs12979860 is located in the intronic region of a novel gene, IFNLA, and is in high linkage disequilibrium (LD) with an IFNLA exonic frameshift polymorphism rs368234815-TT/ $\Delta \mathrm{G}$, initially designated as ss469415590 (Prokunina-Olsson and others 2013). The rs368234815- $\Delta \mathrm{G}$ allele, which creates an open reading frame for a novel human interferon, interferon lambda 4
(IFN- $\lambda 4$ ), is associated with decreased HCV clearance (Prokunina-Olsson and others 2013) [reviewed in O'Brien and others (2014)]. The rs368234815- $\Delta \mathrm{G}$ has allele frequency of $\sim 70 \%$ in individuals of African ancestry, $\sim 30 \%$ in Europeans, while only $0 \%-5 \%$ in Asians (ProkuninaOlsson and others 2013). In individuals of African ancestry, rs368234815 is more predictive of HCV clearance than rs12979860 (Prokunina-Olsson and others 2013; Aka and others 2014); while in Europeans and Asians, these markers are in high LD and thus provide comparable predictive information (Prokunina-Olsson and others 2013).

A genetic polymorphism rs117648444-C/T, which introduces an amino-acid substitution P70S in the IFN- $\lambda 4$ protein (Prokunina-Olsson and others 2013), is associated with reduced biological activity of IFN- $\lambda 4$ and increased HCV clearance (Terczynska-Dyla and others 2014), thereby supporting the critical role of IFN- $\lambda 4$ in this process. Recent clinical trials showed that IFNLA variants rs368234815 and rs12979860 are predictive of treatment efficacy even for DAA therapies (Fujino and others 2013; Meissner and others

Laboratory of Translational Genomics, Division of Cancer Epidemiology and Genetics, National Cancer Institute, National Institutes of Health, Bethesda, Maryland.

(C) Olusegun O. Onabajo et al. 2015; Published by Mary Ann Liebert, Inc. This Open Access article is distributed under the terms of the Creative Commons Attribution Noncommercial License (http://creativecommons.org/licenses/by-nc/4.0/) which permits any noncommercial use, distribution, and reproduction in any medium, provided the original author(s) and the source are credited. 
2014a; O'Brien and Pfeiffer 2015) and these markers, possibly together with P70S, could be used to optimize treatment regimens and duration in resource-limited settings.

The functional importance of IFN- $\lambda 4$ is evidenced by the strong positive selection that favored elimination of IFN- $\lambda 4$ from human populations (Key and others 2014). Although this selection cannot be explained by any known viral infection, it may reflect antiviral response to some extinct highly deadly infection. Previously, we showed that transient transfection of an expression construct that generates IFN- $\lambda 4$ protein induced interferon signaling, with activation of interferon-stimulated genes (ISGs) and generation of antiviral response in HepG2, a human hepatoma cell line (Prokunina-Olsson and others 2013). However, the function of IFN- $\lambda 4$ and its role in impaired HCV clearance remained unclear. Here, we further explored this question by performing additional functional analyses of IFN$\lambda 4$ transiently and stably overexpressed in human hepatic cells_-fresh primary hepatocytes and HepG2 cells.

\section{Materials and Methods}

\section{Cells}

The human hepatoma cell line HepG2 (ATCC HB-8065) was purchased from the American Tissue Culture Collection (ATCC) and maintained in Dulbecco's modified Eagle's medium (DMEM) supplemented with $10 \%$ heat-inactivated fetal bovine serum (FBS). The custom ISRE-Luc-HepG2 cell line stably expressing a luciferase reporter under control of the interferon-stimulated response element (ISRE) was previously described (Prokunina-Olsson and others 2013); the cells were maintained in DMEM supplemented with $10 \% \mathrm{FBS}$ and $2 \mu \mathrm{g} / \mathrm{mL}$ puromycin.

Fresh primary human hepatocytes (PHHs) were purchased from Bioreclamation IVT. The cells were received in suspension within $6 \mathrm{~h}$ after isolation and were maintained in InVitroGRO HI culture media with Torpedo antibiotic mix. The liver donor 1 was a 55-year-old woman who died of cardiac arrest, and the liver donor 2 was a 40-year-old man who died of anoxia. Both were HCV-free Caucasians. On arrival, PHHs had $88 \%$ and $90 \%$ viability for donor 1 and 2, respectively. DNA extracted from the PHHs was genotyped with a custom TaqMan assay (Prokunina-Olsson and others 2013) for the exonic IFNL4 genetic variant rs368234815 ( $\Delta \mathrm{G} / \mathrm{TT})$. Both donors were homozygous for the rs368234815-TT allele, which is associated with higher HCV clearance (ProkuninaOlsson and others 2013). The rs368234815-TT allele introduces a frame shift within the first exon of IFNL4 gene and eliminates the IFN- $\lambda 4$ protein. Thus, no IFN- $\lambda 4$ protein could be endogenously produced in these $\mathrm{PHH}$ samples.

\section{Expression constructs}

The expression constructs (IFNL4-Halo, p131-Halo, and control-Halo) based on the pFC14A vector (Promega) were previously described (Prokunina-Olsson and others 2013). The control-Halo construct generates only a Halo-tag protein $(33 \mathrm{kDa})$, the IFNL4-Halo construct generates the IFN$\lambda 4$-Halo protein $(53 \mathrm{kDa})$ consisting of the IFN- $\lambda 4$ protein $(20 \mathrm{kDa}) \mathrm{C}$-terminally fused with the Halo-tag protein $(33 \mathrm{kDa})$, and the p131-Halo generates a protein of $47 \mathrm{kDa}$, consisting of the Halo-tag C-terminally fused with a splicing protein isoform of IFN- $\lambda 4$ (131 aa, $14 \mathrm{kDa}$, designated as p131), which lacks exon 3 and is nonfunctional in induction of interferon response (Prokunina-Olsson and others 2013). All constructs have been validated by Western blotting with an $\alpha$-Halo antibody (Promega) and/or an $\alpha$-IFN- $\lambda 4$ antibody (MABF227; EMD Millipore). The IFNL3-Halo construct generating the secreted IFN- $\lambda 3$-Halo protein was created and validated the same way.

\section{Transient transfections}

HepG2 cells and PHHs were transfected for 24 or $48 \mathrm{~h}$ with corresponding constructs; HepG2 cells were transfected using Lipofectamine/LTX and Opti-MEM with standard protocols (Life Technologies), while PHHs were transfected using a nucleofection protocol optimized for primary cells (Lonza). Briefly, for each transfection, $2 \times 10^{6}$ fresh PHHs were resuspended in $100 \mu \mathrm{L}$ of optimized nucleofection buffer L3 and transfected with $5 \mu \mathrm{g}$ of corresponding constructs using 4D-nucleofector (Lonza). Immediately after transfection, dead cells were separated by centrifugation ( $4 \mathrm{~min}, 570 \mathrm{rpm}$ ) of the transfection mix overlaid with $900 \mu \mathrm{L}$ of Ficoll (GE Healthcare) and $750 \mu \mathrm{L}$ of supernatant with dead cells was removed. The remaining cells were resuspended in InVitroGRO CP media with Torpedo antibiotic mix (Bioreclamation IVT), plated onto collagen-coated plates (BD Biosciences), and incubated overnight. Unattached and dead cells were removed $12 \mathrm{~h}$ post-transfection by replacing the transfection media with InVitroGRO HI culture media with Torpedo antibiotic mix (Bioreclamation IVT).

\section{Development of inducible stable HepG2 cell lines}

Tetracycline-inducible HepG 2 cell lines for IFN- $\lambda 4$-GFP, p131-GFP, and control-GFP were generated using the TetOn $3 \mathrm{G}$ expression system (Clontech). First, a stable HepG2 cell line expressing the Tet-On 3G transactivator was generated by lentiviral transduction and blasticidin selection $(5 \mu \mathrm{g} / \mathrm{mL})$. Corresponding cDNAs were cloned into a pTREG3G plasmid (Clontech) to generate tetracyclineinducible IFN- $\lambda 4$-GFP, p131-GFP, and control-GFP constructs, which were transfected into the stable Tet-On 3G-HepG2 using Lipofectamine/LTX. Positive clones were identified by limiting dilution under neomycin selection $(1 \mathrm{mg} / \mathrm{mL})$ over 3 weeks. Expression of corresponding proteins was induced by treatment with $1 \mu \mathrm{g} / \mathrm{mL}$ doxycycline for indicated experiment-specific time periods.

\section{Live cell imaging}

HepG2 cells were transfected with corresponding constructs in 4 -well coverslip chambers $\left(4 \times 10^{4}\right.$ cells/well; LabTek). After $24 \mathrm{~h}$, transfection media was replaced with live cell imaging solution (Life Technologies), supplemented with $20 \mathrm{mM}$ glucose. Cell-permeant Halo-tag ligands (TMR red or Oregon green; Promega) were added to live cells $(1: 2,000$ for $15 \mathrm{~min})$, and live imaging was performed using a LSM700 confocal laser scanning microscope (Carl Zeiss) fitted with a temperature and $\mathrm{CO}_{2}$-controlled chamber. When applicable, nuclei were visualized using fluorescent Hoechst 33342 dye (Life Technologies). For cell death analysis, live cells were imaged using inverted oil lens at $40 \times$ magnification, with $6 \mathrm{~s}$ scanning per minute per field of view for $18 \mathrm{~h}$, generating 1,080 images per field; 6 fields were imaged in sequence using stage-positioning software. Each field of view had at least 10 transfected cells. Signs of 
cell death were scored visually by counting membrane rupture events in the videos representing the 18-h imaging periods. Cell death rates were determined as the percentages of ruptured cells of the total counts of fluorescent cells in each field of view.

\section{Fluorescence recovery after photobleaching}

HepG2 cells were transfected with corresponding constructs and imaged live as described earlier using Oregon green Halo-tag ligand. The mobility of the IFN- $\lambda 4-$ Halo and control-Halo proteins was evaluated with fluorescence recovery after photobleaching (FRAP) method (Snapp and others 2003). Briefly, after 10 prebleach scans, a selected region was bleached at $100 \%$ of imaging power with 3 iterations and $2 \mu \mathrm{s}$ per iteration, with $1.94 \mathrm{~s}$ per scan. Imaging was continued for a total of $150 \mathrm{~s}$. Fluorescence intensity was plotted with curve fitting to evaluate fluorescence recovery in the bleached areas over time. Half-time fluorescence recovery $\left(t^{1} / 2\right)$ and the ratio of immobile fraction were averaged for 7 individually scanned cells for each construct (IFNL4-Halo and control-Halo). Recovery data were normalized to unbleached regions inside the cells and adjusted for background fluorescence; data acquisition and analyses were performed using LSM700 FRAP software.

\section{Blocking of IFN- $\lambda 4$ activity}

The stable HepG2-ISRE-Luc cells were seeded in 96-well plates that were either untransfected or transfected with corresponding constructs. After $24 \mathrm{~h}$, the cells were treated for $2 \mathrm{~h}$ with the following antibodies: $20 \mu \mathrm{g} / \mathrm{mL}$ of a blocking $\alpha$ IL10R2 antibody (R\&D Systems), $40 \mu \mathrm{g} / \mathrm{mL}$ of a goat isotype IgG control (Abcam), a range $(20,10,5,2.5$, or $1.25 \mu \mathrm{g} / \mathrm{mL})$ of a custom rabbit monoclonal $\alpha$-IFN- $\lambda 4$ antibody (ProkuninaOlsson and others 2013), or $40 \mu \mathrm{g} / \mathrm{mL}$ of a rabbit isotype $\mathrm{IgG}$ control (Cell Signaling). Recombinant human interferons$10 \mathrm{ng} / \mathrm{mL}$ of custom IFN- $\lambda 3$ (Prokunina-Olsson and others 2013), IFN- $\alpha$ and IFN- $\beta$ (PBL Assay Science), or IFN- $\gamma$ (R\&D Systems) were added to the untransfected cells pretreated with the antibodies. Negative controls included nontreated cells, phosphate-buffered saline (PBS) in media, and mock transfection with control-Halo constructs. The cells were assayed for luciferase expression of the ISRE-Luc reporter $48 \mathrm{~h}$ post-transfection. All transfections and treatments were done in 8 biological replicates. For other experiments, inducible stable HepG2 cells were seeded into 96-well plates and protein expression was induced for $12 \mathrm{~h}$. Antibodies $(20 \mu \mathrm{g} / \mathrm{mL}$ of rabbit monoclonal $\alpha$-IFN- $\lambda 4$ or $40 \mu \mathrm{g} / \mathrm{mL}$ of rabbit $\mathrm{IgG}$ control) were added to shared culture media for $48 \mathrm{~h}$.

\section{Transwell assays}

HepG2 and PHHs were transfected with corresponding constructs and seeded onto 6-well plates. Separately, transwell inserts with $0.4 \mu \mathrm{M}$ pores (Corning) were seeded with untransfected cells and placed into 6-well plates with culture media, with 1 insert per well. For PHHs, both the plates and transwell inserts were collagen coated (Corning). After $24 \mathrm{~h}$, media was replaced and transwell inserts with growing cells were added to the plates containing transfected cells. The pore size of transwell inserts allowed free circulation of the media but not of the cells.
For PHHs from donor 2, the transwell experiment was expanded to include antibody treatment. PHHs transfected with IFNL4-Halo, IFNL3-Halo, and control-Halo constructs were incubated with transwell inserts seeded with untransfected PHHs. Antibodies $(20 \mu \mathrm{g} / \mathrm{mL}$ of rabbit monoclonal $\alpha$-IFN- $\lambda 4$ or $40 \mu \mathrm{g} / \mathrm{mL}$ of rabbit IgG control) were added to shared culture media for $24 \mathrm{~h}$. After $24 \mathrm{~h}$ of coincubation, cells from both chambers that shared culture media (transfected vs. untransfected transwell cells) were collected separately for RNA extraction and stored in RLT buffer; shared culture media was collected for protein analysis and stored at $-80^{\circ} \mathrm{C}$ until use.

\section{Cell death, proliferation, and viability assays}

For transient transfections, HepG2 cells were transfected with corresponding constructs for $48 \mathrm{~h}$ and media was changed after overnight incubation. Expression of Halo-tag in live cells was detected using cell-permeant Halo-tag TMR red ligand. For stable HepG2 cells, expression of proteins was induced for $72 \mathrm{~h}$. In both systems, dead cells were identified using near-IR fixable Live/Dead marker (Life Technologies). For analysis of apoptosis, cells were additionally stained for Annexin V (BD Biosciences). For proliferation assays, the cells that were induced for $72 \mathrm{~h}$ were treated with $10 \mu \mathrm{M}$ 5-bromo-2'-deoxyuridine (BrdU) for $3 \mathrm{~h}$. Dead cells were excluded by removing nonadherent cells, and the remaining cells were stained using the APC BrdU flow kit (BD Biosciences). Multiparametric flow cytometry analysis was performed on FACS Aria III (BD Biosciences) with FlowJo.10 software (Tree Star). For viability assays, the protein expression was induced for 5 days in 96-well plates and viability was evaluated with the Multi Tox-Glo assay (Promega). In some experiments, viability assays were performed after protein induction for $72 \mathrm{~h}$, with similar results.

\section{Quantitative reverse-transcriptase-polymerase chain reaction expression analysis}

Total RNA was isolated using an RNeasy kit with oncolumn DNase I treatment (Qiagen). RNA quantity and quality were evaluated by NanoDrop 8000 (Thermo Scientific). cDNA was prepared from 40 to $100 \mathrm{ng}$ of total RNA with the $\mathrm{RT}^{2}$ first-strand cDNA kit and random hexamers with an additional DNA-removal step (Qiagen). Quantitative reverse-transcriptase-polymerase chain reaction (qRTPCR) mRNA expression analysis was performed using SYBR Green Antiviral Response qRT-PCR plates (Qiagen). The plates included 88 expression assays for target genes, as well as positive, negative, and endogenous normalization controls (Supplementary Tables S1-S3; Supplementary Data are available online at www.liebertpub.com/jir). A custom expression assay for IFNL3 (Prokunina-Olsson and others 2013) and predesigned TaqMan expression assays for IFNL1 (Hs00601677_g1) and IFNG (Hs00989291_m1; Life Technologies) were not included on the predesigned plates and were used separately (Supplementary Table S4).

The qRT-PCR reactions ( 5 or $10 \mu \mathrm{L}$ ) included expression master mixes (Qiagen or Life Technologies), cDNA, and corresponding expression assays; the quantification was performed in 2-4 technical replicates on the QuantSudio 7 instrument (Life Technologies). Expression was measured 
in $C_{\mathrm{t}}$ values (PCR cycle at detection threshold), which are distributed on $\log _{2}$ scale. Expression was normalized by the geometric means of 5 endogenous controls (ACTB, $B 2 M, G A P D H, H P R T 1, R P L P O)$ included on the qRT-PCR plates or of 2 endogenous controls used separately (assay 4326317E for GAPDH, and assay 4326315E for ACTB; Life Technologies). Differences in expression were calculated according to the relative quantification method, as $\Delta C_{\mathrm{t}}=C_{\mathrm{t}}$ (control) $-C_{\mathrm{t}}$ (target). Fold differences between expression of any 2 samples or groups of samples were calculated as $2^{(\Delta C \mathrm{t} 1-\Delta C \mathrm{t} 2)}$. Heat-map analysis of auto-scaled expression data for a panel of selected ISGs was performed with the GenEx software (MultiD).

\section{Detection of IP-10 with ELISA}

Protein levels of IP-10 (encoded by CXCL10) in culture media from HepG2 and PHHs transfected with corresponding constructs were measured with an ELISA kit (R\&D Systems), which has a protein detection range of 7.8$500 \mathrm{pg} / \mathrm{mL}$. Culture media was collected $24 \mathrm{~h}$ after transfection media change ( $48 \mathrm{~h}$ post-transfection). Media samples were diluted 1:10 or 1:20, and each sample was measured in technical triplicates. A standard curve was generated using the protein provided with the kit, with a correlation coefficient $>0.98$. The plates were analyzed using GloMax luminometer (Promega).

\section{Detection of IFN- $\lambda 4$ with MesoScale}

IFN- $\lambda 4$ was detected with a custom-developed electrochemical ELISA on the Meso QuickPlex SQ120 instrument [MesoScale Discovery (MSD)]. Briefly, standard capacity multi-array 96-well plates (MSD) were coated overnight at $4^{\circ} \mathrm{C}$ with $30 \mu \mathrm{L}$ of $2 \mu \mathrm{g} / \mathrm{mL}$ custom monoclonal rabbit $\alpha$ IFN- $\lambda 4$ antibody. Blocking was performed with bovine serum albumin (MSD blocker $\mathrm{A}$ ) for $1 \mathrm{~h}$ at room temperature with rotation at $400 \mathrm{rpm}$, followed by 3 washes with PBS and $0.05 \%$ Tween. Standards, controls, and experimental samples were prepared using diluent 2 (MSD).

Culture media samples were diluted 1:10 and incubated at room temperature for $2 \mathrm{~h}$ with rotation at $400 \mathrm{rpm}$. After additional wash steps, $25 \mu \mathrm{L}$ of the $4 \mu \mathrm{g} / \mathrm{mL}$ detection antibody [mouse monoclonal $\alpha$-IFN- $\lambda 4$ antibody (buffer exchanged into PBS, MABF227; EMD Millipore)], conjugated with a sulfo-tag (MSD) was added to the wells and incubated for $1 \mathrm{~h}$ at room temperature with rotation at $400 \mathrm{rpm}$. After additional washing, the plates were scanned in a $2 \times$ read buffer (MSD) on the Meso QuickPlex SQ120 and the results were analyzed with the MSD Discovery Workbench software. Purified recombinant IFN- $\lambda 4$ protein (ProkuninaOlsson and others 2013) was used as a standard at 9 concentrations in the range of $46 \mathrm{pg} / \mathrm{mL}$ to $300 \mathrm{ng} / \mathrm{mL}$, and the detection range for the standards was determined as $150 \mathrm{pg} /$ $\mathrm{mL}$ to $300 \mathrm{ng} / \mathrm{mL}$.

\section{Analysis of unfolded protein response with ERSE-Luc reporter}

HepG2 cells were transfected for $48 \mathrm{~h}$ with $50 \mathrm{ng}$ of corresponding constructs with/without cotransfection with $1.0 \mu \mathrm{L}$ of the endoplasmic reticulum stress response element (ERSE)-Luc Cignal Reporter (Qiagen). Transfections were done in a 96-well plate, with 8 replicates per transfection.
Media was changed $24 \mathrm{~h}$ post-transfection, and the plate was assayed for luciferase and renilla using the GloMax luminometer. Data were presented as relative luciferase units, which correspond to luciferase/renilla ratio.

\section{JAK and IL10R2 blocking assays in HepG2-ISRE-Luc cells}

The stable HepG2-ISRE-Luc cells were transfected with corresponding constructs in 96-well plates; untransfected cells were treated with human recombinant interferons-IFN$\alpha(2 \mathrm{ng} / \mathrm{mL}$; PBL Assay Science) or custom IFN- $\lambda 3$ (10 ng/ $\mathrm{mL}$ ). All experiments were represented by 8 biological replicates. The media was replaced $24 \mathrm{~h}$ post-transfection by $100 \mu \mathrm{L}$ of full culture media with 1 or $10 \mu \mathrm{M} \mathrm{JAK}$ inhibitor [active against JAK1, JAK2, and JAK3, \#420097; EMD Millipore, in $0.1 \%$ dimethyl sulfoxide (DMSO)]. For IL10R2 blocking experiment, the transfection culture media was replaced by $100 \mu \mathrm{L}$ of media with $20 \mu \mathrm{g} / \mathrm{mL}$ of an $\alpha$-IL10R2 blocking antibody (MAB874; R\&D Systems) or $20 \mu \mathrm{g} / \mathrm{mL}$ of a goat isotype IgG control (Abcam).

For treatment experiments, cells were pretreated for $1 \mathrm{~h}$ with the JAK inhibitor or for $2 \mathrm{~h}$ with the $\alpha$-IL10R2 or IgG control antibodies and then treated with IFN- $\lambda 3(10 \mathrm{ng} / \mathrm{mL})$ or IFN- $\alpha$ $(2 \mathrm{ng} / \mathrm{mL})$. Negative controls included untreated cells, cells treated with $0.1 \%$ DMSO in media, and cells transfected with control-Halo construct. The cells were assayed for ISRE-Luc reporter $48 \mathrm{~h}$ post-transfection, which corresponds to $24 \mathrm{~h}$ posttreatment with JAK inhibitor and antibodies.

\section{siRNA silencing of IFNLR1 in HepG2-ISRE-Luc cells}

The stable HepG2-ISRE-Luc cells were transfected with corresponding constructs in 2 identical 96-well plates. The cells were co-transfected with $1 \mathrm{pmol} /$ well of a scrambled negative control siRNA (AM4615; Ambion) or a set of siRNAs against IFNLRI (M-007981-00; Thermo Scientific). After $24 \mathrm{~h}$, the cells were treated with culture media, IFN- $\lambda 3$ $(10 \mathrm{ng} / \mathrm{mL})$, or IFN- $\alpha(2 \mathrm{ng} / \mathrm{mL})$. After $48 \mathrm{~h}$, the first plate was assayed for the ISRE-Luc reporter on the GloMax luminometer. The second plate was used for RNA extraction (Zymo Research) and mRNA expression analysis. cDNA was synthesized using Super Script III reverse transcriptase (Life Technologies).

Specific TaqMan assays for IFNLRI (Hs00417120_m1) and endogenous control ACTB (assay 4326315E) from Life Technologies were used for qRT-PCR analysis on the QuantStudio 7 instrument (Life Technologies). Expression of IFNLRI was normalized to expression of $A C T B$ and then expression in samples treated with IFNLRI siRNA was compared with untreated samples (no siRNA) or treated with scrambled siRNA. All samples were represented by 6 biological replicates. Compared with siRNA-untreated samples (100\%), the expression of IFNLRI was decreased to $76 \%$ in si-Scr samples and to $42 \%$ in si-IFNLR1 samples (Supplementary Fig. S1D).

\section{Statistical analysis}

Unless specified, data plotting and statistical analyses were performed with Prism 6 (GraphPad), $P$ values are for 2 -sided unpaired $t$-tests. Shown are means and standard errors of the mean. 


\section{Results}

IFN- $\lambda 4$ is secreted, and its activity is blocked by a monoclonal $\alpha-I F N-\lambda 4$ antibody

Previously, by performing Western blot analysis, we were unable to detect IFN- $\lambda 4$ in culture media of HepG 2 cells transiently transfected with an IFN- $\lambda 4$-producing construct, even though this transfection resulted in strong activation of interferon signaling (Prokunina-Olsson and others 2013). However, IFN- $\lambda 4$ was detectable at low levels in culture media of transfected cells by Western blot analysis after acetone precipitation (Hamming and others 2013). Now, we developed a MesoScale assay (an electrochemical ELISA) and were able to detect IFN- $\lambda 4$ in culture media of transfected HepG2 cells (Fig. 1A). Treatment of these cells with a custom $\alpha$-IFN- $\lambda 4$ antibody decreased the interferon signaling by $70 \%$ (Fig. 1B), suggesting that IFN- $\lambda 4$ generated in this experimental system is a secreted biologically active interferon. Simultaneously, the $\alpha$-IFN- $\lambda 4$ antibody did not affect signaling of the main interferons (IFN- $\alpha$, IFN- $\beta$, IFN$\gamma$, and IFN- $\lambda 3$, Fig. $1 C$ ). Signaling induced by IFN- $\lambda 4$ was strongly attenuated by the JAK inhibitor and by blocking of the IFN- $\lambda$ family receptors (IFNLR1 and IL10R2, Supplementary Fig. S1A-C), confirming these canonical components of the JAK/STAT pathway as essential elements for the IFN- $\lambda 4$ signaling.

\section{Secreted IFN- $\lambda 4$ induces ISGs in hepatic cells}

We evaluated the biological activity of the secreted IFN$\lambda 4$ by its ability to induce expression of a set of ISGs (Supplementary Tables S1-S3). We analyzed mRNA ex- pression in cells transiently transfected with IFNL4-Halo or control-Halo constructs and in bystander nontransfected cells exposed to media from the corresponding transfected cells in transwell assays (IFNL4-trans and Halo-trans, Fig. 2A). In both HepG2 and PHHs, cells transfected with IFNL4-Halo or exposed to media from those cells (containing secreted IFN- $\lambda 4$ ) showed strong induction of ISGs, such as DDX58 (RIG-I), DHX58, IFIH1 (MDA5), ISG15, $M X 1, O A S 2$, and STAT1 and chemokines CXCL10 and CXCL11 (Fig. 2A). Expression of CXCL1O and CXCL11 was much higher in PHHs compared with HepG2, highlighting cell-specific differences (Fig. 2A). IFN- $\lambda 4$ was detectable in culture media of IFNL4-transfected PHHs and HepG2 cells, but not in corresponding Halo-transfected cells (Fig. 2B). We did not detect expression of other interferons (IFNA1, IFNA2, IFNB, IFNG, IFNL1, IFNL3) in any of the experimental conditions (Supplementary Table S4).

CXCL10 encodes IFN- $\gamma$ inducible protein 10 (IP-10), which is a chemotactic factor for neutrophils. High levels of IP-10 have been associated with inflammation and pathogenesis of chronic HCV infection (Harvey and others 2003; Lagging and others 2006). We measured the levels of IP-10 in culture media of PHHs and HepG2 transfected with different constructs. In PHHs, IP-10 was detectable in the media from samples transfected with IFNL4-Halo and IFNL3-Halo (Fig. 3B), while it was undetectable in HepG2 cells transfected with IFNL4-Halo (data not shown), in accordance with a much lower CXCL10 mRNA expression observed in HepG2 compared with PHHs (Supplementary Tables S1-S3). Importantly, the $\alpha$-IFN- $\lambda 4$ antibody added to the shared media strongly decreased mRNA expression of ISGs, including CXCL10, in nonexpressing transwell
FIG. 1. IFN- $\lambda 4$ is secreted, and its ability to induce ISRE-Luc is blocked by an $\alpha$-IFN- $\lambda 4$ antibody. (A) IFN- $\lambda 4$ is detectable with a MesoScale assay in culture media of HepG2 cells transfected with IFNL4-Halo but not with control-Halo construct; results are shown in biological duplicates with means. (B) Effects of $\alpha$-IFN- $\lambda 4$ $(0-20 \mu \mathrm{g} / \mathrm{mL}), \alpha$-IL10R2 $(20 \mu \mathrm{g} / \mathrm{mL})$, and $\mathrm{IgG}$ control $(40 \mu \mathrm{g} / \mathrm{mL})$ antibodies on IFN- $\lambda 4$ signaling in HepG2-ISRELuc cells, normalized to cells transfected with the IFNL4-Halo construct but not treated with any antibody (marked as a dashed line at 100\%), all in 8 biological replicates. (C) Effects of $\alpha$-IFN- $\lambda 4$ and $\alpha$-IL10R2 $(20 \mu \mathrm{g} / \mathrm{mL})$ and $\mathrm{IgG}$ control $(40 \mu \mathrm{g} / \mathrm{mL})$ antibodies on signaling of IFN- $\lambda 4$ and human recombinant purified interferonsIFN- $\lambda 3$, IFN- $\alpha$, IFN- $\beta$, or IFN- $\gamma$ in HepG2-ISRE-Luc cells, all in 8 biological replicates. NS, not significant. $* * * * P<10^{-5}$ based on $t$-tests. IFN- $\lambda 4$, interferon lambda 4; ISRE, interferonstimulated response element.

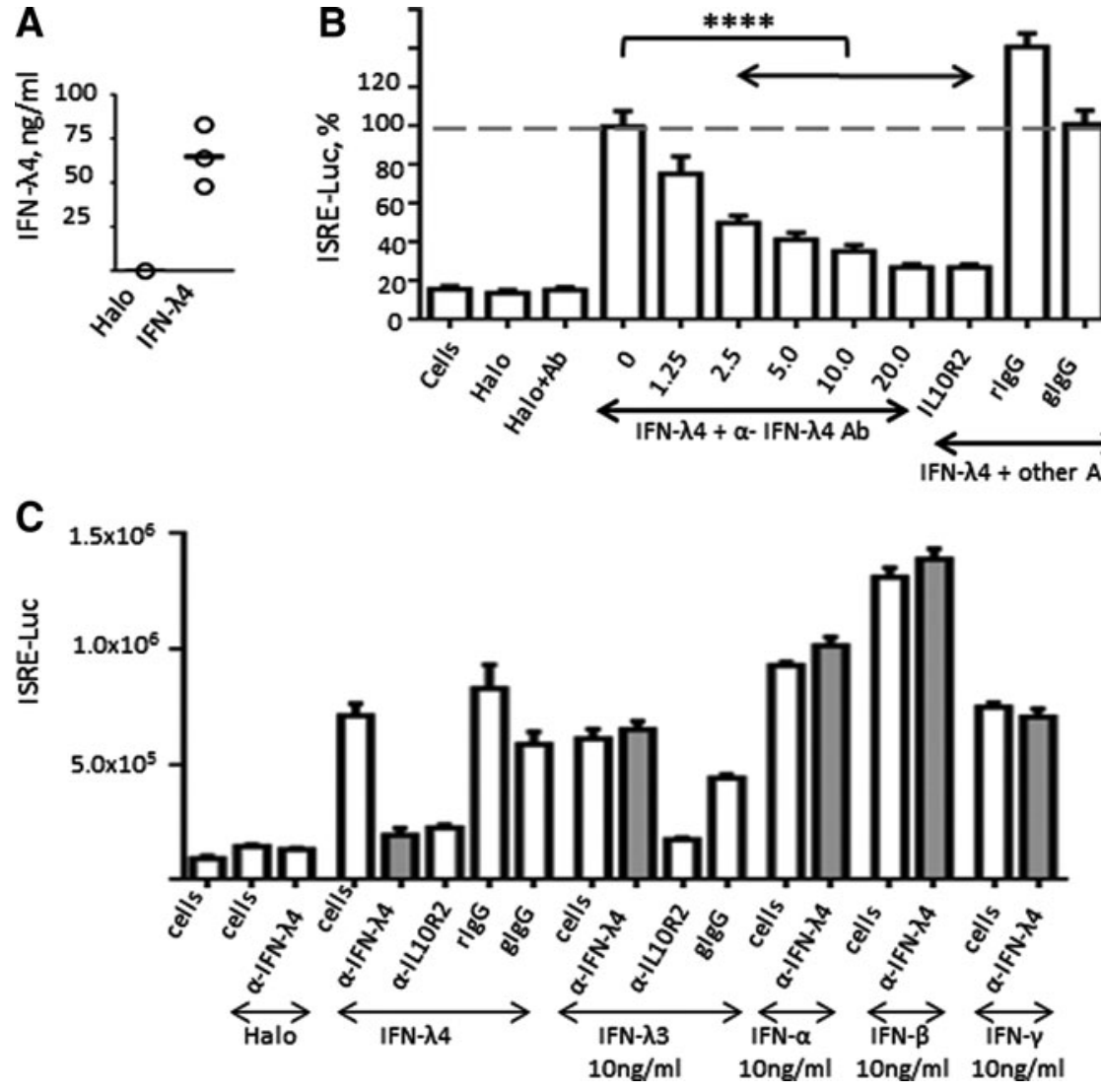




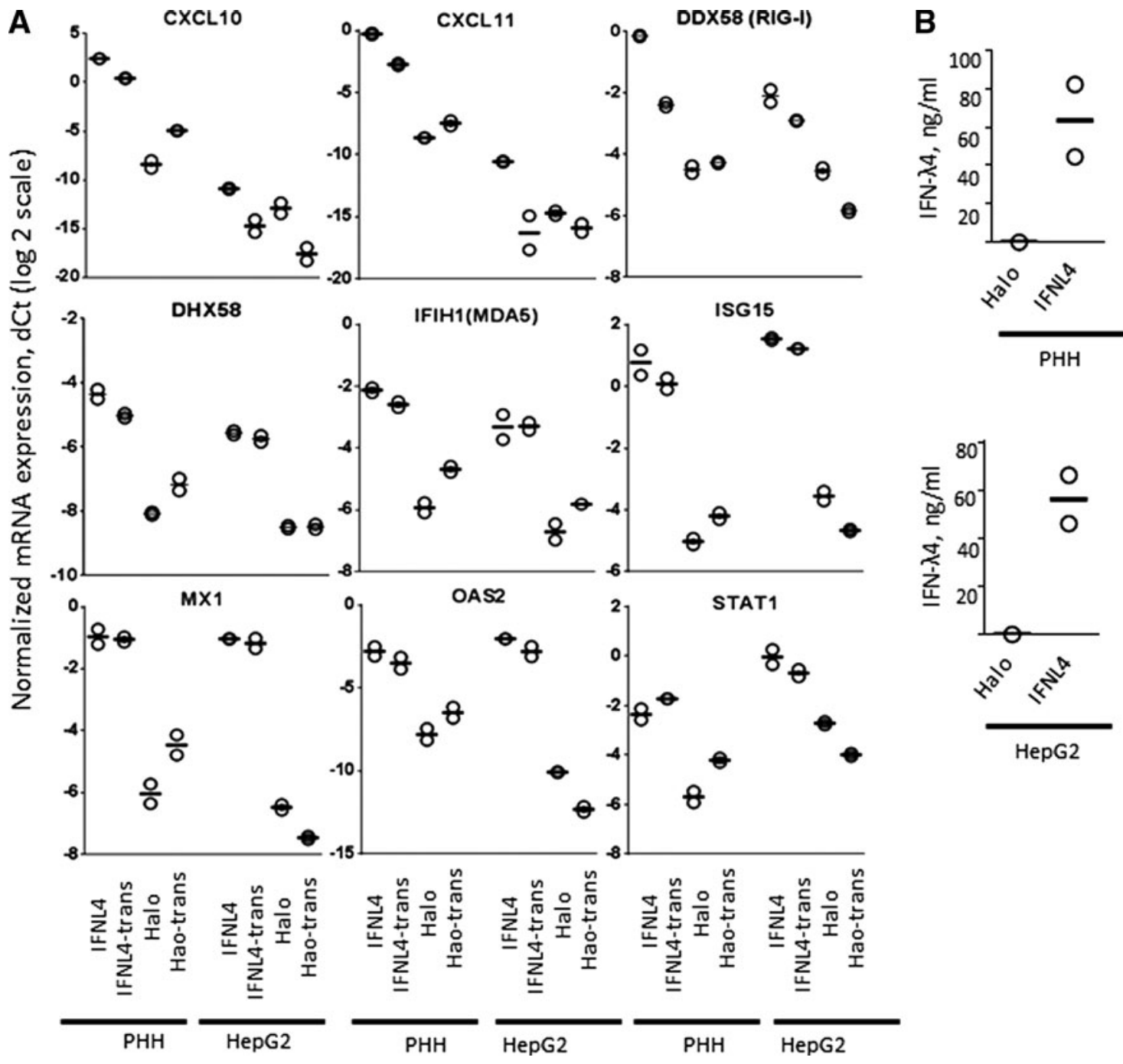

FIG. 2. Expression of ISGs in IFNL4-Halo-transfected and bystander untransfected cells in HepG2 and PHHs. (A) Expression of mRNA transcripts was quantified using an antiviral response qRT-PCR plate. The cells were transfected with corresponding constructs for $48 \mathrm{~h}$, and transwell cells shared culture media with the corresponding transfected cells for $24 \mathrm{~h}$. All samples were represented by 2 biological replicates. Expression of each target assay on the plate was measured using the same amount of cDNA; expression was normalized to a geometric mean of 5 endogenous controls included on the plate. The results are presented as $\mathrm{dC}_{\mathrm{t}}$ values for targets normalized by endogenous controls, on a log 2 scale; less negative $\mathrm{dC}_{\mathrm{t}}$ values correspond to higher levels of expression. Full expression data for HepG2 cells and PHH are available as Supplementary Tables S1 and S2. (B) Protein levels of IFN- $\lambda 4$ in the same amount of culture media ( $30 \mu \mathrm{L})$ from HepG2 cells and PHHs transfected with IFNL4-Halo and control-Halo constructs for $48 \mathrm{~h}$. Culture media was shared with corresponding nontransfected cells in the transwell assays described in section (A). IFN- $\lambda 4$ was measured in culture media collected from 2 independent transfections per construct and cell type. ISGs, interferon-stimulated genes; qRT-PCR, quantitative reversetranscriptase-polymerase chain reaction.

PHHs (Fig. 3A) and the amount of IP-10 secreted to the shared media (Fig. 3A, B).

\section{Large proportion of IFN- $\lambda 4$ is retained intracellularly}

Even though some of IFN- $\lambda 4$ gets secreted, as described earlier, IFN- $\lambda 4$ was also detected as a cytoplasmic protein by confocal imaging in fixed cells-in HepG2 cells transiently expressing IFN- $\lambda 4-H a l o$, and in PHHs induced to express endogenous IFN- $\lambda 4$ (Prokunina-Olsson and others 2013). We next performed live imaging of intracellular movements of IFN- $\lambda 4$-Halo and control-Halo proteins (Supplementary Video S1). We also monitored FRAP (Fig. 4A). This method does not detect secreted proteins such as IFN- $\lambda 3$, but it helps characterize intracellular proteins based on their mobility (Fig. 4B), which is proportional to the speed of fluorescence recovery $\left(t^{1} / 2\right.$, in seconds). The control-Halo protein showed very high mobility, with a $t^{1 / 2}$ of $4.46 \pm 1.19$ s (Fig. $4 \mathrm{C}$ and Supplementary Video S2), while IFN- $\lambda 4$-Halo showed a much lower mobility, with a $t^{1 / 2}$ of $34.69 \pm 6.94 \mathrm{~s}$ (Fig. 4C and Supplementary Video S3).

Intracellular mobility of proteins could be limited by their attachment to structural elements, involvement in proteinprotein interactions, or confinement within vesicles (Lippincott-Schwartz and others 2001; Snapp and others 2003). Therefore, we also estimated the fraction of immobile 

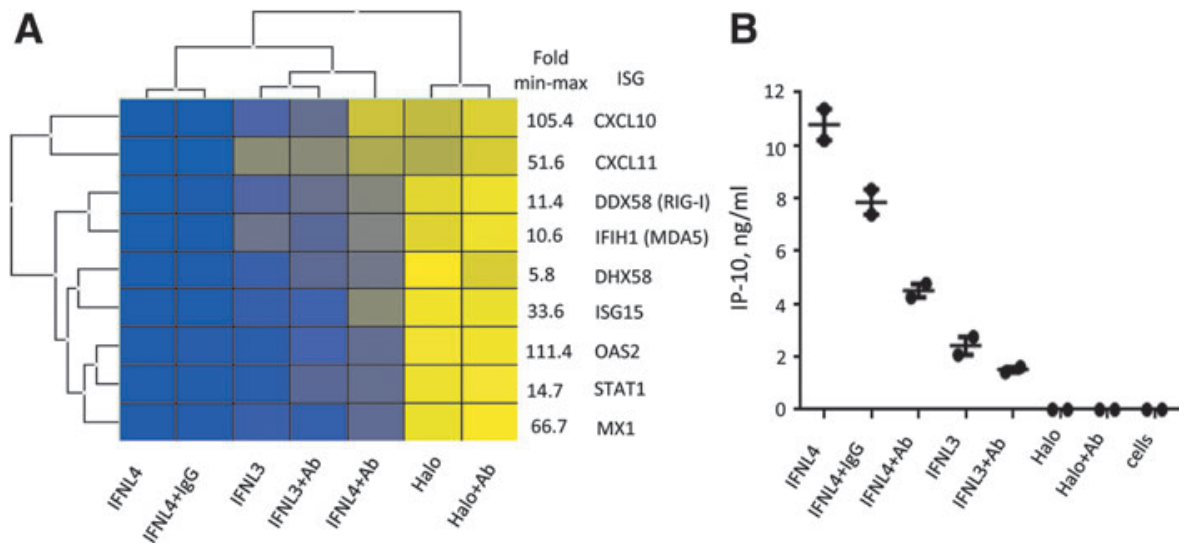

FIG. 3. $\alpha$-IFN- $\lambda 4$ antibody inhibits activation of ISGs induced by the secreted IFN- $\lambda 4$. (A) Unsupervised clustering and heat map based on auto-scaled expression data for the same ISGs as presented in Fig. 2, but using PHHs from a different liver donor. Presented data are for transwell PHHs, which shared media with transfected cells for $24 \mathrm{~h}$. The transwell cells were exposed to media of PHHs transfected with IFNL4-Halo, IFNL3-Halo, or control-Halo, with and without treatment of culture media with $20 \mu \mathrm{g} / \mathrm{mL}$ of $\alpha$-IFN- $\lambda 4$ antibody or $40 \mu \mathrm{g} / \mathrm{mL}$ of isotype IgG control. Blue (dark) indicates higher expression, whereas yellow (light) indicates lower expression; fold difference is between the most distant samples on the heatmap-IFNL4-Halo-transfected sample (high) and Halo-transfected and $\alpha$-IFN- $\lambda$ 4-treated sample (low). (B) IP-10 protein expression profile in culture media of PHHs transfected with IFNL4-Halo, IFNL3-Halo, and control-Halo, with or without $\alpha$-IFN- $\lambda 4$ antibody treatment, all in biological duplicates.

FIG. 4. IFN- $\lambda 4$ is retained intracellularly in transfected HepG2 cells. (A) FRAP analysis in HepG2 cells transfected with IFNL4-Halo or control-Halo constructs (green fluorescence). (B) Fluorescence recovery for the first $100 \mathrm{~s}$ after photobleaching of IFN$\lambda 4$-Halo and control-Halo proteins within the areas marked with white rectangles $(\mathbf{A})$. Recovery is presented as a ratio to the prebleached fluorescence levels (1.0); immobile fraction is marked by an arrow. (C) Fluorescence recovery rate ( $t^{1 / 2} 2$, in seconds) and (D) $\%$ of immobile fraction in the marked areas on (A). The plots and statistical analyses are for average values of 7 cells individually assayed in FRAP experiments. $* * P<0.01$, based on $t$-tests, scale bars, $10 \mu \mathrm{m}$. FRAP, fluorescence recovery after photobleaching. Blue-nuclei staining, green fluorescence represents Halo-tagged proteins.
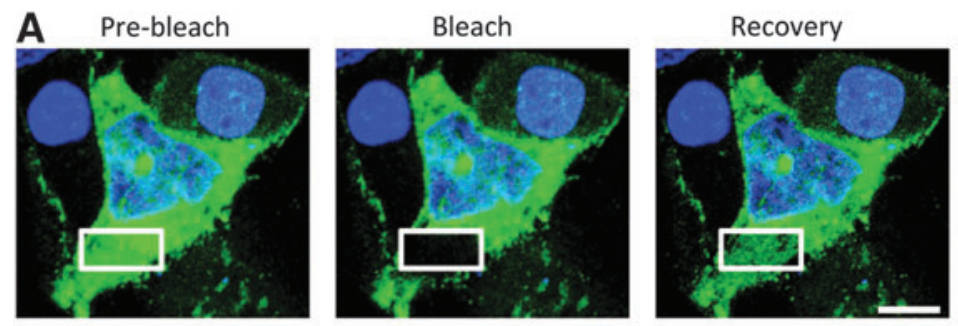

IFN- $\lambda 4+$
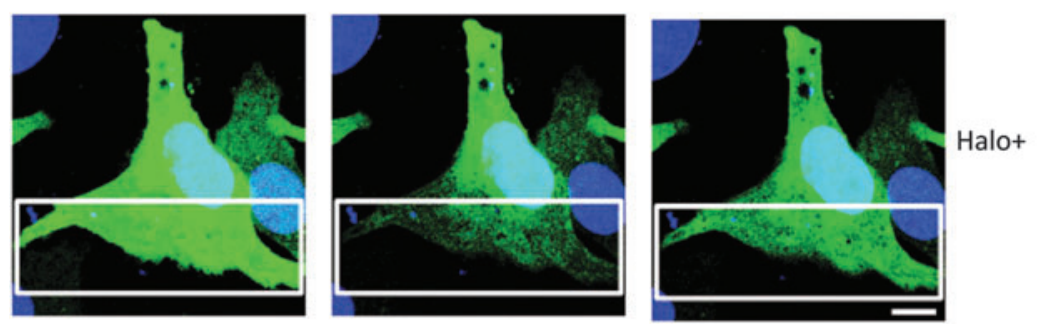

B
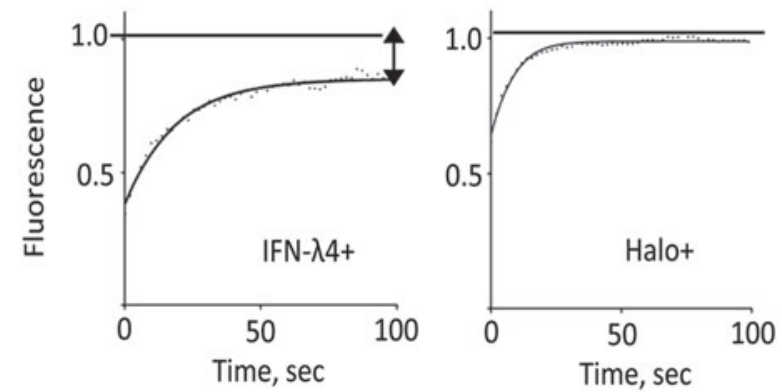

C
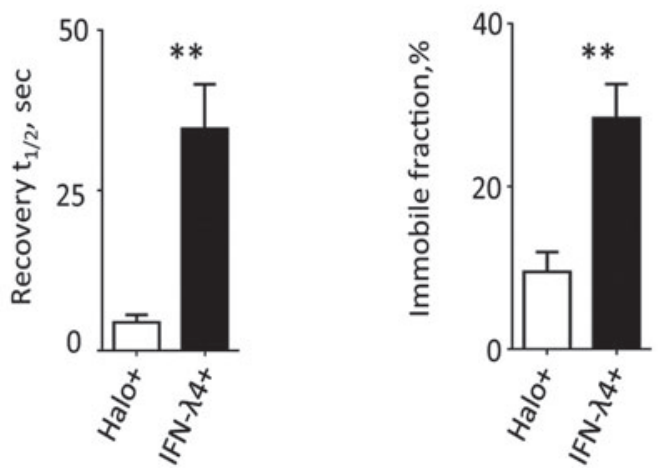
protein, which is represented by unrecoverable fluorescence-nearly $30 \%$ of IFN- $\lambda 4$-Halo $(28.43 \% \pm 4.22 \%)$ compared with $\sim 10 \%$ of control-Halo protein $(9.58 \% \pm 2.43 \%)$ was estimated to be immobile (Fig. 4D). We conclude that in our experimental system the control-Halo was mostly present as a mobile unattached cytoplasmic protein, in agreement with other studies that used Halo-protein (Huybrechts and others 2009). In contrast, we detected IFN- $\lambda 4$-Halo both as an intracellularly retained protein with limited mobility and as a mobile protein potentially available for secretion or release.

\section{IFN- $\lambda 4$ causes cell death}

While conducting live confocal imaging in transiently transfected HepG2 cells, we observed dying cells that underwent morphologic changes of swelling, membrane blebbing, and rupture, followed by release of cytoplasmic content (Fig. 5A, B and Supplementary Videos S4-S6), suggesting necrotic-type cell death (Fiers and others 1999; Festjens and others 2006; Galluzzi and others 2012). Cell rupture events over the course of $18 \mathrm{~h}$ of imaging were significantly more

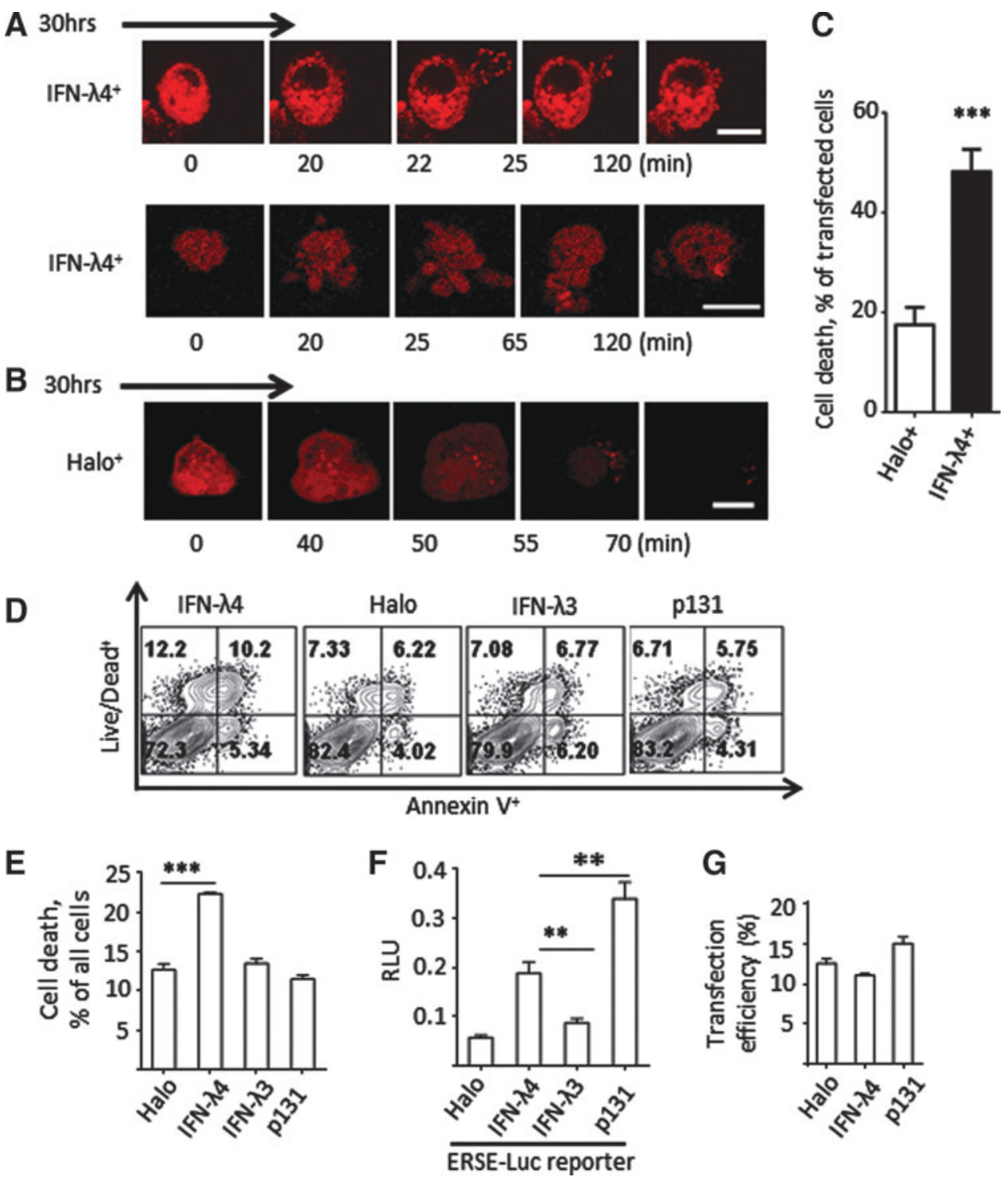

FIG. 5. IFN- $\lambda 4$ induces cell death in transfected HepG 2 cells. Live confocal imaging of IFN- $\lambda 4-\mathrm{Halo}$ (A) or control-Halo (B)-expressing cells undergoing cell death, both labeled with red fluorescent ligand. Shown are representative snapshots of individual scans presented in Supplementary Videos S4-S6; starting at 30 h post-transfection. (C) Percentage of HepG2 cells that underwent cell rupture after transient transfection with IFNL4-Halo compared with control-Halo constructs, during the 18-h imaging period. Results represent an average of 2 independent biological experiments. (D) Representative flow cytometry plots of cell viability analyzed with Live/Dead and Annexin V markers. After transfection of HepG2 cells with indicated constructs, media was replaced $24 \mathrm{~h}$ post-transfection to remove dead cells and the remaining cells were analyzed $48 \mathrm{~h}$ post-transfection. (E) Summary graphs for data in (D). Dead cells are those positive for Live/Dead marker (upper 2 quadrants), $(n=3)$. (F) Analysis of unfolded protein response in HepG2 cells co-transfected with indicated expression constructs and the ERSE-Luc reporter and analyzed $48 \mathrm{~h}$ post-transfection. (G) Graph showing transfection efficiency of HepG2 cells for indicated constructs. RLU, relative luciferase units, $* * P<0.01$, $* * * P<0.001$, based on $t$-tests, scale bar, $10 \mu \mathrm{m}$. ERSE, endoplasmic reticulum stress response element. 

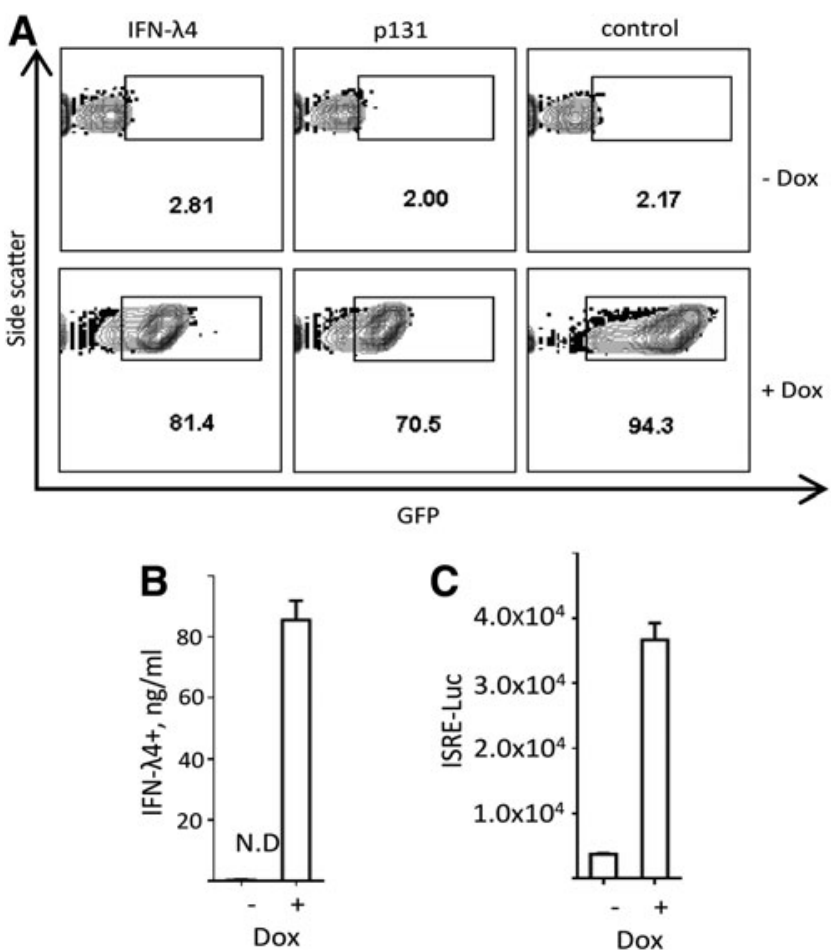

FIG. 6. Development of stable inducible HepG2 cell lines. (A) Flow cytometry plots of GFP expression after induction of IFN- $\lambda 4-G F P, p 131-G F P$, or control-GFP in stable HepG2 cells with $1 \mu \mathrm{g} / \mathrm{mL}$ doxycycline for $48 \mathrm{~h}$. (B) Detection of IFN- $\lambda 4$ with a MesoScale assay in culture media of IFN $-\lambda 4$ GFP-expressing HepG2 cells with or without induction, $n=3$, N.D., no detection (C). Media from IFN- $\lambda 4$-GFP HepG2 cells with or without induction was added to ISRELuc-HepG2 cells for $24 \mathrm{~h}$, and activation of interferon signaling (ISRE-Luc) was evaluated. Shown are mean values of 6 biological replicates. GFP, green fluorescent protein. frequent in IFN $-\lambda 4^{+}$compared with control-Halo ${ }^{+}$HepG2 cells (Fig. 5C). Flow cytometry analysis showed that necrotic cells (defined as Annexin $\mathrm{V}^{+}$and Live/Dead ${ }^{+}$) were significantly more common in cells transfected with IFNL4-Halo compared with p131-Halo (a nonfunctional protein isoform of IFN- $\lambda 4$ ), IFNL3-Halo, and control-Halo constructs (Fig. 5D, E). Transfection efficiency was comparable for all these constructs (Fig. 5G, but could not be determined for the secreted IFNL3-Halo), and thus could not explain the observed differences in cell death. We also evaluated cell death in PHHs transiently transfected with IFNL4-Halo or controlHalo constructs. In general, in PHHs, cell death rates were very high even in untransfected cells and similar for both constructs (data not shown), possibly due to physiologically high baseline cell death rates in primary cells unrelated to the effect of IFN- $\lambda 4$.

Cell death can also be triggered as a result of an endoplasmic reticulum response to unfolded recombinant proteins generated in vitro. Previously, we showed that transient expression of IFNL4-Halo and its splicing forms-p131, p107, and p170 - induced the ERSE-Luc reporter in HepG2 cells (Prokunina-Olsson and others 2013). We next repeated this experiment for the ERSE-Luc reporter cotransfected with IFNL4-Halo or p131-Halo. Transfection with p131Halo did not induce cell death (Fig. 5D, E), despite considerable induction of the ESRE-Luc reporter (Fig. 5F). We conclude that potential activation of the unfolded protein response to in vitro generated IFN- $\lambda 4$ cannot explain the observed IFN- $\lambda 4$-induced cell death.

In an effort to define the mechanism of IFN- $\lambda 4$-induced cell death, we assayed for RIPK1-dependent necrosis (necroptosis) and caspase-1-dependent cell death (pyroptosis), using specific inhibitors (necrostatin and YVAD). However, we saw no evidence of the activation of these pathways after transient transfection with the IFNL4-Halo construct (data not shown). Treatment with ZVAD, a pan-caspase inhibitor, caused a significant decrease in IFN- $\lambda 4$-induced cell death, which is suggestive of apoptosis, but this effect was also
A

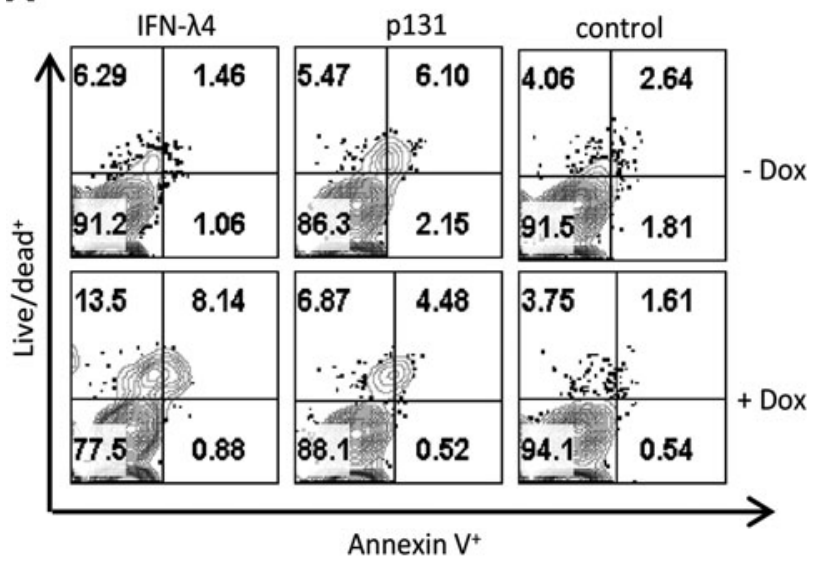

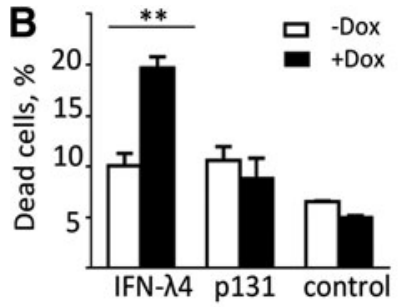

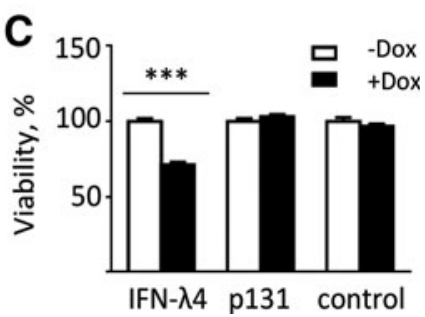

FIG. 7. Induction of IFN- $\lambda 4$ expression causes cell death. Protein expression of IFN- $\lambda 4-G F P$, p131-GFP, or control-GFP in stable HepG2 cells was induced with $1 \mu \mathrm{g} / \mathrm{mL}$ doxycycline for $72 \mathrm{~h}$. (A) Cell viability was evaluated with Live/Dead and Annexin V markers. (B) Summary graphs of data on (A). Dead cells are those positive for Live/Dead marker (upper 2 quadrants). Graphs represent 1 of 3 independent experiments, $n=3$. (C) Cell viability was analyzed with Multi Tox-Glo assay and presented as the percentage of induced to uninduced cells, $n=6$. $* * P<0.01, * * * P<0.001$, based on $t$-tests. 


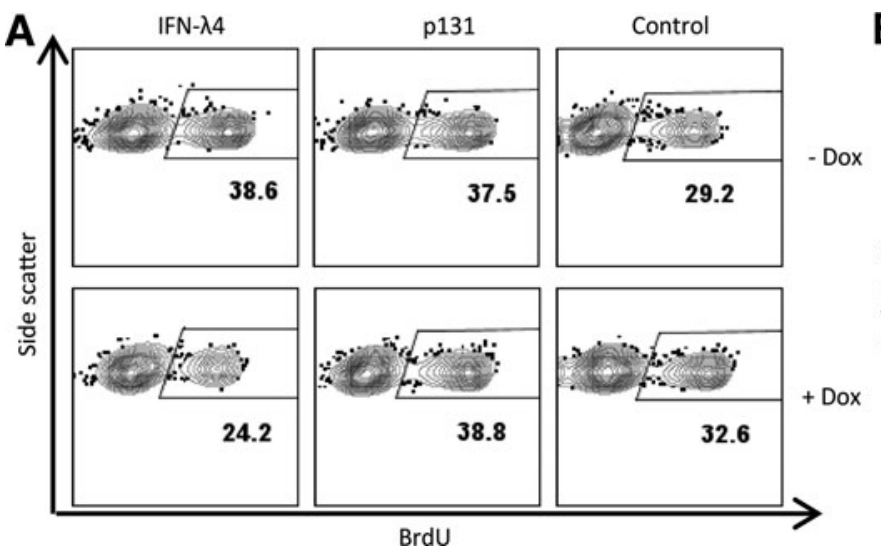

B

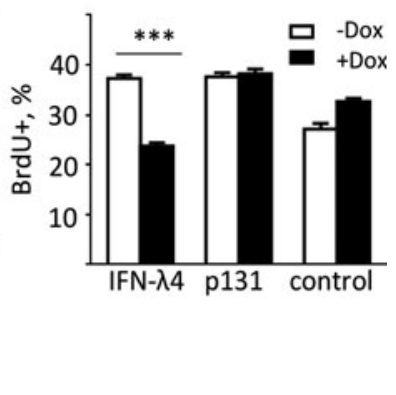

FIG. 8. Induction of IFN- $\lambda 4$ expression inhibits cell proliferation. (A) Protein expression of IFN- $\lambda 4-G F P$, p131GFP, or control-GFP in stable HepG2 cells was induced with $1 \mu \mathrm{g} / \mathrm{mL}$ doxycycline for $72 \mathrm{~h}$. For cell proliferation analysis, cells were incubated with $1 \mu \mathrm{M}$ BrdU for $3 \mathrm{~h}$ and stained with $\alpha$-BrdU antibody. (B) Summary graphs of data in $(\mathbf{A})$. Graphs represent 1 of 3 independent experiments, $n=3$, *** $P<0.001$, based on $t$-tests. BrdU, 5-bromo-2'deoxyuridine.

observed in controls (data not shown), implying that transfection itself might be contributing to apoptosis in this experimental system.

\section{Induction of stable IFN- $\lambda 4$ expression causes cell death and decreased cell proliferation}

To further explore our observations done in transient expression system, we developed inducible stable HepG2 cell lines expressing IFN- $\lambda 4$ and p131 fused with C-terminal green fluorescent protein (GFP) and a control-GFP cell line, all of which were under control of a tetracycline-inducible promoter. Stable clones showed $70 \%-90 \%$ intracellular expression (Fig 6A). Secreted IFN- $\lambda 4$-GFP was detectable in media after $24 \mathrm{~h}$ of induction (Fig. 6B) and was biologically active (Fig. 6C). To assess cell death, protein expression was induced for $72 \mathrm{~h}$ and cells were stained for Live/Dead ${ }^{+}$and Annexin $\mathrm{V}^{+}$markers. The IFN- $\lambda$ 4-GFP-expressing cells showed a significant increase in cell death compared with cells expressing p131-GFP or control-GFP (Fig. 7A, B).

In addition, cell viability analysis showed that 5 days of induced IFN- $\lambda 4$ expression resulted in a $30 \%$ reduction in the counts of viable cells compared with uninduced cells, with no change observed for the controls (Fig. 7C). Although we observed increased Annexin $\mathrm{V}^{+}$staining in the induced IFN- $\lambda 4$-expressing cells (Fig. 7A) suggesting apoptotic cell death, we did not detect any caspase- 3 activation (data not shown), which is expected in apoptosis. We reasoned that cell death might be associated with decreased proliferation, and we evaluated cell proliferation after $72 \mathrm{~h}$ of induced IFN- $\lambda 4$ expression by measuring BrdU incorporation. Compared with p131-GFP and GFP control, induction of IFN- $\lambda 4$ was associated with a significant reduction of proliferation by $40 \%$ (Fig. 8 A, B).

\section{$\alpha-I F N-\lambda 4$ antibody inhibits IFN- $\lambda 4$-induced cell death and proliferation defect}

We induced IFN- $\lambda 4$ expression in the presence or absence of the rabbit monoclonal $\alpha$-IFN- $\lambda 4$ antibody, which we previously found to be able to block the ability of IFN$\lambda 4$ to induce interferon signaling (Fig. 1). The $\alpha$-IFN- $\lambda 4$ antibody treatment attenuated IFN- $\lambda 4$-induced cell death (Fig. 9A), while it increased proliferation (Fig. 9B) and improved cell viability (Fig. 9C). Since the antibody is not expected to enter the cells and can only block the secreted protein, these results indicate that the observed cell death and decreased viability and proliferation are caused by the secreted IFN- $\lambda 4$. Interestingly, this effect was localized to IFN- $\lambda 4$-expressing cells and was undetectable in nonexpressing bystander cells in the transwell assays (Supplementary Fig. S2). Thus, the effect of IFN- $\lambda 4$ may be concentration dependent and primarily affecting the IFN$\lambda 4$-expressing cells.
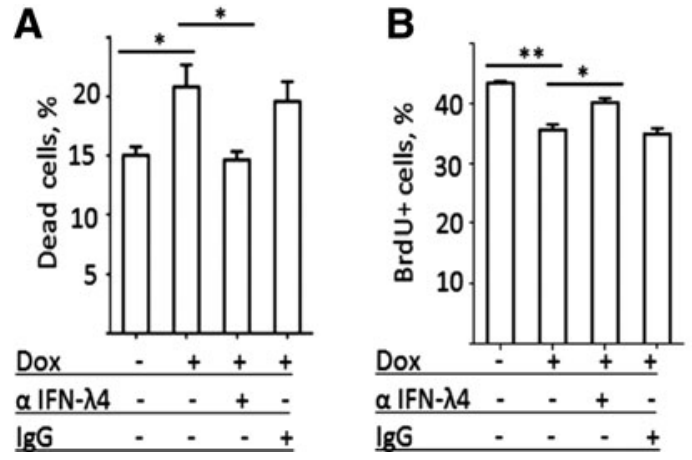

FIG. 9. $\alpha$-IFN- $\lambda 4$ antibody inhibits IFN$\lambda 4$-induced cell death and proliferation defect. Protein expression of IFN- $\lambda 4$-GFP, p131GFP, or control-GFP in stable HepG2 cells was induced with $1 \mu \mathrm{g} / \mathrm{mL}$ doxycycline for $72 \mathrm{~h}$. At $12 \mathrm{~h}$, cells were treated with $20 \mu \mathrm{g} /$ $\mathrm{mL}$ of rabbit $\alpha$-IFN- $\lambda 4$ antibody or $40 \mu \mathrm{g} / \mathrm{mL}$ of rabbit IgG control (rIgG). Cells in different treatment conditions were assessed for cell death (A), cell proliferation (B), and cell viability (C). Graphs represent 1 of 2 independent experiments, $n=3$, $* P<0.05$, $* * P<0.01$, $* * * P<0.001$ based on $t$-tests. 


\section{Discussion}

We suggest that IFN- $\lambda 4$ may have at least 3 functions in human hepatic cells - activation of interferon signaling, inhibition of cell proliferation, and induction of cell death. These roles may be overlapping, synergistic, or independent, and some or all of them may be relevant for HCV clearance.

Activation of ISGs by IFN- $\lambda 4$ was expected based on our previous observations in transiently transfected HepG2 cells (Prokunina-Olsson and others 2013). Early activation of a panel of ISGs has also been reported in both in vitro HCVinfected and adjacent uninfected PHHs (Sheahan and others 2014). However, we now determined the following about IFN- $\lambda 4$-induced ISG activation: it is specifically caused by the IFN- $\lambda 4$ secreted from cells at low but detectable amounts; it has an effect on both primary hepatocytes and hepatoma cells; it similarly affects the expressing and nonexpressing bystander cells; and it can be specifically blocked by the $\alpha$-IFN- $\lambda 4$ antibody.

Anti-proliferative and cell-death-inducing anti-tumor effects are, in general, characteristic of interferons (Wang and others 2011), including in hepatoma cell lines (Murata and others 2006). However, we now present the first evidence of these effects caused by IFN- $\lambda 4$, the newest addition to the interferon family. While activation of ISGs was observed in both the IFN- $\lambda 4$-expressing and nonexpressing bystander cells, the decrease of proliferation and induction of cell death were detectable only in the expressing cells. This could mean that these effects require different concentration thresholds.

The dose-dependent anti-proliferative effect in hepatic cells has already been shown for IFN- $\alpha$ (Lim and others 2006), and the same might be true for IFN- $\lambda 4$. Anti-proliferative activity of IFN- $\lambda 4$ is ISG dependent as it was blocked by the same $\alpha$-IFN- $\lambda 4$ antibody that blocks IFN- $\lambda 4$ induced activation of ISGs. Some of the ISGs induced by IFN- $\lambda 4$, including $2^{\prime} 5^{\prime} \mathrm{OAS}$ and IP-10, are known for their contribution to the anti-proliferative and pro-apoptotic effects of interferons (Rysiecki and others 1989; Hassel and others 1993; Aksoy and others 2006; Liu and others 2011). At this point, we are unable to determine the mechanism of IFN- $\lambda 4$-induced cell death. Although we did not detect activation of caspase- 3 by IFN- $\lambda 4$, therapeutic anti-tumor mechanisms of interferons have been related to cell growth arrest and induction of caspase-3-independent apoptosis via the p53 pathway (Vogelstein and others 2000; Takaoka and others 2003; Takaoka and Taniguchi 2003), and this pathway should be tested for IFN- $\lambda 4$ as well. The effect of IFN- $\lambda 4$ on activation of interferon signaling and cell death might be complex and intertwined, and further studies are warranted.

The genetic association between the ability to generate IFN- $\lambda 4$ (in carriers of the rs $368234815-\Delta \mathrm{G}$ and rs $12979860-$ $\mathrm{T}$ alleles) and impaired spontaneous and treatment-induced clearance of HCV is well established, but the molecular understanding of this association is still limited. Recently, it has also been reported that the same individuals who are more likely to clear the HCV infection, in fact, are significantly more likely to develop liver fibro-proliferative disease (fibrosis), which is associated with increased mortality (Eslam and others 2015). Our new findings regarding IFN- $\lambda 4$ function may help reconcile these counterintuitive connections.
We suggest that the induction of interferon signaling by IFN- $\lambda 4$ may have both positive and negative implications. The IFN- $\lambda 4$-induced ISGs might provide some antiviral protection, explaining the lower pretreatment HCV loads in individuals with the rs368234815- $\Delta \mathrm{G}$ allele, compared with those who do not carry this allele (Uccellini and others 2012). On the other hand, the increased pretreatment expression levels of these ISGs have been associated with refractoriness to IFN- $\alpha$ therapy (Dill and others 2011), especially in carriers of the IFNL4-rs368234815- $\Delta \mathrm{G}$ or rs12979860-T alleles (Urban and others 2010; ProkuninaOlsson and others 2013). This could be because IFN- $\alpha$ and IFN- $\lambda 4$ compete for induction of the same set of ISGs, and, once activated by IFN- $\lambda 4$, these ISGs do not respond to IFN- $\alpha$. The fact that despite having lower pretreatment HCV levels, individuals with rs368234815- $\Delta \mathrm{G}$ allele are more likely to develop chronic HCV and fail IFN- $\alpha$-based treatment, suggests that either negative effects of IFN- $\lambda 4$ outweigh its positive effect on lowering HCV viral load or antiviral effects induced by IFN- $\lambda 4$ are insufficient for complete viral clearance.

The IFN- $\lambda 4$ effect on proliferation and cell death might also be positive and negative. Increased cell death has been correlated with inflammation during HCV infection and was suggested as a factor contributing to liver damage (Bantel and Schulze-Osthoff 2003). High rates of cell death in IFN$\lambda 4$-expressing cells could amount to substantial cell loss and inflammation, contributing to the development of liver disease. Simultaneously, the anti-proliferative effect of IFN- $\lambda 4$ might limit the tissue remodeling ability that leads to liver fibro-proliferative disease (fibrosis), as has been reported by the largest study on this subject to date (Eslam and others 2015). Individuals who are genetically unable to produce IFN- $\lambda 4$ or in whom IFN- $\lambda 4$ is not sufficiently induced by specific stimuli may be more likely to clear the infection, spontaneously or after treatment, especially with IFN- $\alpha$ based therapies. However, they may not have the benefit of an anti-proliferative effect also contributed by IFN- $\lambda 4$, and will be more likely to develop fibrosis.

Since in our system the $\alpha$-IFN- $\lambda 4$ antibody efficiently blocked activation of ISGs (including IP-10), and IFN- $\lambda 4$ induced cell death, blocking of IFN $-\lambda 4$ with therapeutic agents in carriers of the rs368234815- $\Delta \mathrm{G}$ allele might be a plausible therapeutic option before or in conjunction with other treatments. Blocking of IFN- $\lambda 4$ might boost mechanisms of endogenous host immunity, which are important for efficient clearance of $\mathrm{HCV}$ and prevention of posttreatment relapse (Meissner and others 2014b), and also decrease liver damage due to inflammation and cell death.

Although the antiviral role of IFN- $\lambda 4$ has been shown for a number of viruses (Hamming and others 2013; Lu and others 2015), it remains to be found what other biologically relevant factors can trigger endogenous IFN- $\lambda 4$ expression. Identification of these triggers in hepatic and other human cell types could help explore the role of IFN- $\lambda 4$ in other relevant clinical conditions. So far, expression of endogenous IFNLA has only been detected in liver biopsies from patients infected with $\mathrm{HCV}$, with significant correlations between HCV titers and expression levels of IFNL4 and ISGs (Amanzada and others 2013; Konishi and others 2013; Meissner and others 2014b; Murakawa and others 2015). However, IFNL4 was undetectable in liver biopsies from patients infected with hepatitis $B$ virus or affected by 
unrelated liver diseases (Amanzada and others 2013). In vitro, IFNLA expression could be induced in PHHs by HCV infection or treatment with PolyI:C, but PolyI:C treatments failed to induce IFNL4 expression in HepG2 cells. The IFNL4 region is absent in the genomes of mouse and rat, precluding the development of relevant rodent models.

We acknowledge the limitations of our experimental system, which is based on expression of IFN- $\lambda 4$ in human hepatic cells-a hepatoma cell line HepG2 and PHHs. The observed effects might differ from the physiologic conditions in the HCV-infected hepatic cells in the complex whole-organ environment by the magnitude, duration, and efficiency of IFN- $\lambda 4$ induction. We also did not address the mechanism of intracellular retention and the function of the nonsecreted IFN- $\lambda 4$. However, we provide a comprehensive functional analysis of IFN- $\lambda 4$, a novel human interferon, and suggest its role in activation of interferon signaling, inhibition of cell proliferation, and induction of cell death in human hepatic cells.

\section{Acknowledgments}

The work has been supported by the Intramural Research Program (IRP) of the Division of Cancer Epidemiology and Genetics, National Cancer Institute, National Institutes of Health, US, by the NCI Director's Innovation Award to L.P.-O., and the NCI Director's Career Development Award to O.O.O. The authors thank Adeola Obajemu for technical help and staff of the Protein Expression Laboratory and Protein Characterization Laboratory, Frederick National Laboratory for Cancer Research for help with development of stable inducible HepG2 cell lines.

\section{Author Disclosure Statement}

L.P.-O. is a co-inventor on a patent application related to IFN- $\lambda 4$ filed by the NCI.

\section{References}

Aka PV, Kuniholm MH, Pfeiffer RM, Wang AS, Tang W, Chen S, Astemborski J, Plankey M, Villacres MC, Peters MG, Desai S, Seaberg EC, Edlin BR, Strickler HD, Thomas DL, Prokunina-Olsson L, Sharp GB, O'Brien TR. 2014. Association of the IFNL4-DeltaG allele with impaired spontaneous clearance of hepatitis C virus. J Infect Dis 209(3): 350-354.

Aksoy MO, Yang Y, Ji R, Reddy PJ, Shahabuddin S, Litvin J, Rogers TJ, Kelsen SG. 2006. CXCR3 surface expression in human airway epithelial cells: cell cycle dependence and effect on cell proliferation. Am J Physiol Lung Cell Mol Physiol 290(5):L909-L918.

Amanzada A, Kopp W, Spengler U, Ramadori G, Mihm S. 2013. Interferon-lambda4 (IFNL4) transcript expression in human liver tissue samples. PLoS One 8(12):e84026.

Bantel H, Schulze-Osthoff K. 2003. Apoptosis in hepatitis C virus infection. Cell Death Differ 10 (Suppl 1):S48-S58.

Dill MT, Duong FH, Vogt JE, Bibert S, Bochud PY, Terracciano L, Papassotiropoulos A, Roth V, Heim MH. 2011. Interferon-induced gene expression is a stronger predictor of treatment response than IL28B genotype in patients with hepatitis C. Gastroenterology 140(3):1021-1031.

Eslam M, Hashem AM, Leung R, Romero-Gomez M, Berg T, Dore GJ, Chan HL, Irving WL, Sheridan D, Abate ML, Adams LA, Mangia A, Weltman M, Bugianesi E, Spengler
U, Shaker O, Fischer J, Mollison L, Cheng W, Powell E, Nattermann J, Riordan S, McLeod D, Armstrong NJ, Douglas MW, Liddle C, Booth DR, George J, Ahlenstiel G; International Hepatitis CGC. 2015. Interferon-lambda rs12979860 genotype and liver fibrosis in viral and non-viral chronic liver disease. Nat Commun 6:6422.

Festjens N, Vanden Berghe T, Vandenabeele P. 2006. Necrosis, a well-orchestrated form of cell demise: signalling cascades, important mediators and concomitant immune response. Biochim Biophys Acta 1757(9-10):1371-1387.

Fiers W, Beyaert R, Declercq W, Vandenabeele P. 1999. More than one way to die: apoptosis, necrosis and reactive oxygen damage. Oncogene 18(54):7719-7730.

Fujino H, Imamura M, Nagaoki Y, Kawakami Y, Abe H, Hayes CN, Kan H, Fukuhara T, Kobayashi T, Masaki K, Ono A, Nakahara T, Honda Y, Naeshiro N, Urabe A, Yokoyama S, Miyaki D, Murakami E, Kawaoka T, Hiraga N, Tsuge M, Hiramatsu A, Hyogo H, Aikata H, Takahashi S, Miki D, Ochi H, Ohishi W, Chayama K; Hiroshima Liver Study Group. 2013. Predictive value of the IFNL4 polymorphism on outcome of telaprevir, peginterferon, and ribavirin therapy for older patients with genotype $1 \mathrm{~b}$ chronic hepatitis C. J Gastroenterol 49(12):1548-1556.

Galluzzi L, Vitale I, Abrams JM, Alnemri ES, Baehrecke EH, Blagosklonny MV, Dawson TM, Dawson VL, El-Deiry WS, Fulda S, Gottlieb E, Green DR, Hengartner MO, Kepp O, Knight RA, Kumar S, Lipton SA, Lu X, Madeo F, Malorni W, Mehlen P, Nunez G, Peter ME, Piacentini M, Rubinsztein DC, Shi Y, Simon HU, Vandenabeele P, White E, Yuan J, Zhivotovsky B, Melino G, Kroemer G. 2012. Molecular definitions of cell death subroutines: recommendations of the Nomenclature Committee on Cell Death 2012. Cell Death Differ 19(1):107-120.

Ge D, Fellay J, Thompson AJ, Simon JS, Shianna KV, Urban TJ, Heinzen EL, Qiu P, Bertelsen AH, Muir AJ, Sulkowski M, McHutchison JG, Goldstein DB. 2009. Genetic variation in IL28B predicts hepatitis C treatment-induced viral clearance. Nature 461(7262):399-401.

Hamming OJ, Terczynska-Dyla E, Vieyres G, Dijkman R, Jorgensen SE, Akhtar H, Siupka P, Pietschmann T, Thiel V, Hartmann R. 2013. Interferon lambda 4 signals via the IFNlambda receptor to regulate antiviral activity against HCV and coronaviruses. EMBO J 32(23):3055-3065.

Harvey CE, Post JJ, Palladinetti P, Freeman AJ, Ffrench RA, Kumar RK, Marinos G, Lloyd AR. 2003. Expression of the chemokine IP-10 (CXCL10) by hepatocytes in chronic hepatitis $\mathrm{C}$ virus infection correlates with histological severity and lobular inflammation. J Leukoc Biol 74(3):360-369.

Hassel BA, Zhou A, Sotomayor C, Maran A, Silverman RH. 1993. A dominant negative mutant of 2-5A-dependent RNase suppresses antiproliferative and antiviral effects of interferon. EMBO J 12(8):3297-3304.

Huybrechts SJ, Van Veldhoven PP, Brees C, Mannaerts GP, Los GV, Fransen M. 2009. Peroxisome dynamics in cultured mammalian cells. Traffic 10(11):1722-1733.

Key FM, Peter B, Dennis MY, Huerta-Sanchez E, Tang W, Prokunina-Olsson L, Nielsen R, Andres AM. 2014. Selection on a variant associated with improved viral clearance drives local, adaptive pseudogenization of interferon lambda 4 (IFNL4). PLoS Genet 10(10):e1004681.

Konishi H, Motomura T, Matsumoto Y, Harimoto N, Ikegami T, Yoshizumi T, Soejima Y, Shirabe K, Fukuhara T, Maehara Y. 2013. Interferon-lambda4 genetic polymorphism is associated with the therapy response for hepatitis $\mathrm{C}$ virus recurrence after a living donor liver transplant. J Viral Hepat 21(6):397-404. 
Lagging M, Romero AI, Westin J, Norkrans G, Dhillon AP, Pawlotsky JM, Zeuzem S, von Wagner M, Negro F, Schalm SW, Haagmans BL, Ferrari C, Missale G, Neumann AU, Verheij-Hart E, Hellstrand K; DITTO-HCV Study Group. 2006. IP-10 predicts viral response and therapeutic outcome in difficult-to-treat patients with $\mathrm{HCV}$ genotype 1 infection. Hepatology 44(6):1617-1625.

Liang TJ, Ghany MG. 2013. Current and future therapies for hepatitis C virus infection. N Engl J Med 368(20):1907-1917.

Lim R, Knight B, Patel K, McHutchison JG, Yeoh GC, Olynyk JK. 2006. Antiproliferative effects of interferon alpha on hepatic progenitor cells in vitro and in vivo. Hepatology 43(5):1074-1083.

Lippincott-Schwartz J, Snapp E, Kenworthy A. 2001. Studying protein dynamics in living cells. Nat Rev Mol Cell Biol 2(6):444-456.

Liu M, Guo S, Stiles JK. 2011. The emerging role of CXCL10 in cancer (Review). Oncol Lett 2(4):583-589.

Lu YF, Goldstein DB, Urban TJ, Bradrick SS. 2015. Interferonlambda4 is a cell-autonomous type III interferon associated with pre-treatment hepatitis $\mathrm{C}$ virus burden. Virology 476:334-340.

Meissner EG, Bon D, Prokunina-Olsson L, Tang W, Masur H, O'Brien TR, Herrmann E, Kottilil S, Osinusi A. 2014a. IFNL4-DeltaG genotype is associated with slower viral clearance in hepatitis C, genotype-1 patients treated with sofosbuvir and ribavirin. J Infect Dis 209(11):1700-1704.

Meissner EG, Wu D, Osinusi A, Bon D, Virtaneva K, Sturdevant D, Porcella S, Wang H, Herrmann E, McHutchison J, Suffredini AF, Polis M, Hewitt S, Prokunina-Olsson L, Masur H, Fauci AS, Kottilil S. 2014b. Endogenous intrahepatic IFNs and association with IFN-free HCV treatment outcome. J Clin Invest 124(8):3352-3363.

Mohd Hanafiah K, Groeger J, Flaxman AD, Wiersma ST. 2013. Global epidemiology of hepatitis $\mathrm{C}$ virus infection: new estimates of age-specific antibody to $\mathrm{HCV}$ seroprevalence. Hepatology 57(4):1333-1342.

Murakawa M, Asahina Y, Nakagawa M, Sakamoto N, Nitta S, Kusano-Kitazume A, Watanabe T, Kawai-Kitahata F, Otani S, Taniguchi M, Goto F, Nishimura-Sakurai Y, Itsui Y, Azuma S, Kakinuma S, Watanabe M. 2015. Impaired induction of interleukin 28B and expression of interferon lambda 4 associated with nonresponse to interferon-based therapy in chronic hepatitis C. J Gastroenterol Hepatol 30(6):1075-1084.

Murata M, Nabeshima S, Kikuchi K, Yamaji K, Furusyo N, Hayashi J. 2006. A comparison of the antitumor effects of interferon-alpha and beta on human hepatocellular carcinoma cell lines. Cytokine 33(3):121-128.

O'Brien TR, Pfeiffer RM. 2015. Reply: subgroup differences in response to 8 weeks of ledipasvir/sofosbuvir for chronic hepatitis C. Open Forum Infect Dis 1(3):ofu110; DOI: 10.1093/ofid/ofu110.

O'Brien TR, Prokunina-Olsson L, Donnelly RP. 2014. IFNlambda4: the paradoxical new member of the interferon lambda family. J Interferon Cytokine Res 34(11):829-838.

Prokunina-Olsson L, Muchmore B, Tang W, Pfeiffer RM, Park H, Dickensheets H, Hergott D, Porter-Gill P, Mumy A, Kohaar I, Chen S, Brand N, Tarway M, Liu L, Sheikh F, Astemborski J, Bonkovsky HL, Edlin BR, Howell CD, Morgan TR, Thomas DL, Rehermann B, Donnelly RP, O'Brien TR. 2013. A variant upstream of IFNL3 (IL28B) creating a new interferon gene IFNL4 is associated with impaired clearance of hepatitis C virus. Nat Genet 45(2):164-171.
Rysiecki G, Gewert DR, Williams BR. 1989. Constitutive expression of a $2^{\prime}, 5^{\prime}$-oligoadenylate synthetase cDNA results in increased antiviral activity and growth suppression. J Interferon Res 9(6):649-657.

Sheahan T, Imanaka N, Marukian S, Dorner M, Liu P, Ploss A, Rice CM. 2014. Interferon lambda alleles predict innate antiviral immune responses and hepatitis $\mathrm{C}$ virus permissiveness. Cell Host Microbe 15(2):190-202.

Snapp EL, Altan N, Lippincott-Schwartz J. 2003. Measuring protein mobility by photobleaching GFP chimeras in living cells. Curr Protoc Cell Biol Chapter 21:Unit 21.1.

Takaoka A, Hayakawa S, Yanai H, Stoiber D, Negishi H, Kikuchi H, Sasaki S, Imai K, Shibue T, Honda K, Taniguchi T. 2003. Integration of interferon-alpha/beta signalling to p53 responses in tumour suppression and antiviral defence. Nature 424(6948):516-523.

Takaoka A, Taniguchi T. 2003. New aspects of IFN-alpha/beta signalling in immunity, oncogenesis and bone metabolism. Cancer Sci 94(5):405-411.

Terczynska-Dyla E, Bibert S, Duong FH, Krol I, Jorgensen S, Collinet E, Kutalik Z, Aubert V, Cerny A, Kaiser L, Malinverni R, Mangia A, Moradpour D, Mullhaupt B, Negro F, Santoro R, Semela D, Semmo N; Swiss Hepatitis C Cohort Study Group, Heim MH, Bochud PY, Hartmann R. 2014. Reduced IFNlambda4 activity is associated with improved $\mathrm{HCV}$ clearance and reduced expression of interferon-stimulated genes. Nat Commun 5:5699.

Thomas DL, Thio CL, Martin MP, Qi Y, Ge D, O'Huigin C, Kidd J, Kidd K, Khakoo SI, Alexander G, Goedert JJ, Kirk GD, Donfield SM, Rosen HR, Tobler LH, Busch MP, McHutchison JG, Goldstein DB, Carrington M. 2009. Genetic variation in IL28B and spontaneous clearance of hepatitis C virus. Nature 461(7265):798-801.

Uccellini L, Tseng FC, Monaco A, Shebl FM, Pfeiffer R, Dotrang M, Buckett D, Busch MP, Wang E, Edlin BR, Marincola FM, O'Brien TR. 2012. HCV RNA levels in a multiethnic cohort of injection drug users: human genetic, viral and demographic associations. Hepatology 56(1):86-94.

Urban TJ, Thompson AJ, Bradrick SS, Fellay J, Schuppan D, Cronin KD, Hong L, McKenzie A, Patel K, Shianna KV, McHutchison JG, Goldstein DB, Afdhal N. 2010. IL28B genotype is associated with differential expression of intrahepatic interferon-stimulated genes in patients with chronic hepatitis C. Hepatology 52(6):1888-1896.

Vogelstein B, Lane D, Levine AJ. 2000. Surfing the p53 network. Nature 408(6810):307-310.

Wang BX, Rahbar R, Fish EN. 2011. Interferon: current status and future prospects in cancer therapy. $\mathrm{J}$ Interferon Cytokine Res 31(7):545-552.

Address correspondence to: Dr. Ludmila Prokunina-Olsson Laboratory of Translational Genomics Division of Cancer Epidemiology and Genetics National Cancer Institute National Institutes of Health 8717 Grovemont Circle Bethesda, MD 20892-4605

E-mail: prokuninal@mail.nih.gov

Received 12 September 2014/Accepted 27 May 2015 